\title{
NOTES
}

\section{Synthesis of Optically Active Aromatic Poly(ether ketone)s via Nucleophilic Aromatic Substitution Polymerization}

\author{
Katsuya Maeyama, ${ }^{1, \dagger}$ Izumi Hikis,,${ }^{1}$ Kashiko Ogura, ${ }^{1}$ Akiko OKAmoto, ${ }^{1}$ \\ Kenji OGINO, ${ }^{2}$ Hiromu SAITO, ${ }^{1}$ and Noriyuki YoneZAwA ${ }^{1, \dagger}$ \\ ${ }^{1}$ Department of Organic and Polymer Materials Chemistry, Graduate School, Tokyo University \\ of Agriculture and Technology, 2-24-16 Naka-cho, Koganei 184-8588, Japan \\ ${ }^{2}$ Graduate School of Bio-Applications and Systems Engineering, Tokyo University \\ of Agriculture and Technology, 2-24-16 Naka-cho, Koganei 184-8588, Japan
}

(Received February 16, 2005; Accepted May 24, 2005; Published September 15, 2005)

\begin{abstract}
KEY WORDS 2,2'-Dimethoxybinaphthyl / 4,4'-Oxybiphenol / Nucleophilic Aromatic Substitution Polymerization / Optically Active / Thermal Resistibility /

[DOI 10.1295/polymj.37.707]
\end{abstract}

2,2'-Disubstituted 1,1'-binaphthyls such as BINAP have axial asymmetry and have been applied to asymmetric organic reactions. ${ }^{1}$ Polymeric binaphthylene derivatives are requisite for recyclable asymmetric organic catalysts and materials. There have been several reports on polymers containing $2,2^{\prime}$-disubstituted 1,1'-binaphthylene units in the main chains, e.g. polyphenylenes, polycarbonates, polyamides, polyarylates, and polyimides. ${ }^{2-8}$ On the other hand, aromatic polyketones such as poly(ether ketone), i.e., PEEK $^{\circledR}$ have much attention in the field of highperformance materials. ${ }^{9-12}$ We have also studied on the syntheses of wholly aromatic polyketones via electrophilic aromatic substitution acylation polymerization $^{13-18}$ or via nickel-complex mediated aromatic coupling polymerization. ${ }^{19-23}$ However, there have been no reports on the syntheses of aromatic polyketones containing 2,2'-disubstituted 1,1'-binaphthylene units. Introduction of these optically active units to aromatic polyketones would contribute to creation of novel types of high-performance chiral reagents and materials.

In this paper, we would like to report successful synthesis of aromatic poly(ether ketone)s containing $2,2^{\prime}$-dimethoxy-1,1'-binaphthyl-6,6'-ene unit in the main chains via regioselective bis(4-fluorobenzoylation) of (S)-2,2'-dimethoxy-1,1'-binaphthyl (1) and the nucleophilic aromatic substitution polymerization of the resulting bis(fluorobenzoylated) binaphthyl (3) with aromatic diols 4.

\section{EXPERIMENTAL}

\section{General}

${ }^{1} \mathrm{H}$ and ${ }^{13} \mathrm{C}$ NMR spectra were recorded on a JEOL JNM-AL300 (H, $300 \mathrm{MHz} ; \mathrm{C}, 75 \mathrm{MHz})$. Chemical shifts are expressed in ppm relative to internal standards of $\mathrm{Me}_{4} \mathrm{Si}(\mathrm{H} ; \delta, 0.00)$ and $\mathrm{CDCl}_{3}(\mathrm{C} ; \delta, 77.0)$. IR measurement was recorded on a JEOL FR/IR-5300. Inherent viscosities $\left(\eta_{\text {inh }}\right)$ were determined in a concentrated $\mathrm{H}_{2} \mathrm{SO}_{4}\left(0.3 \mathrm{~g} \mathrm{dL}^{-1}\right)$ solution at $30^{\circ} \mathrm{C}$ using an Ostwald viscometer. Glass transition temperatures $\left(T_{\mathrm{g}}\right.$ 's) were determined on the basis of DSC curves. DSC curves were recorded on a SEIKO DSC-200 differential scanning calorimeter with a heating rate of $10 \mathrm{~K} \mathrm{~min}^{-1}$ under nitrogen. Thermal degradation temperature $\left(T_{\mathrm{d}}\right)$ was determined on the basis of a TGA thermogram. The TGA thermogram was recorded on a SEIKO TG/DTA-200 thermogravimeter with a heating rate of $10 \mathrm{~K} \mathrm{~min}^{-1} \cdot \mathrm{P}_{2} \mathrm{O}_{5}-\mathrm{MsOH}$ mixture was prepared according to Eaton's procedure. ${ }^{24}$

\section{6,6'-Bis(4-fluorobenzoyl)-2,2'-dimethoxy-1,1'-binaphthyl} (3)

2,2'-Dimethoxy-1,1'-binaphthyl (1, $0.2 \mathrm{mmol}, 63$ $\mathrm{mg}$ ) and 4-fluorobenzoic acid (2, $0.4 \mathrm{mmol}, 56 \mathrm{mg})$ were placed to a two-necked flask under nitrogen atmosphere. To the flask, $\mathrm{P}_{2} \mathrm{O}_{5}-\mathrm{MsOH}(0.4 \mathrm{~mL})$ was added. The reaction mixture was stirred for $24 \mathrm{~h}$ at rt or $60^{\circ} \mathrm{C}$. The reaction mixture was poured into water slowly. The mixture was extracted with chloroform three times and the extracts were washed with brine and dried over anhydrous $\mathrm{Na}_{2} \mathrm{SO}_{4}$. The solvent

${ }^{\dagger}$ To whom correspondence should be addressed (Tel: +81-42-388-7475/7053, FAX: +81-42-388-7291, E-mail: maeyama@cc.tuat.ac.jp, yonezawa@cc.tuat.ac.jp). 
was removed under reduced pressure. Recrystalization from chloroform/ethanol afforded a white powder of binaphthyl 3 quantitatively.

IR $v(\mathrm{KBr}): 1655,1599,1477,1277,1249 \mathrm{~cm}^{-1}$.

${ }^{1} \mathrm{H}$ NMR $(300 \mathrm{MHz}) \delta\left(\mathrm{CDCl}_{3}\right): 3.83(3 \mathrm{H}, \mathrm{s}), 7.17$ $(2 \mathrm{H}, \mathrm{d}, J=8.4 \mathrm{~Hz}), 7.19(4 \mathrm{H}, \mathrm{t}, J=8.4 \mathrm{~Hz}), 7.54$ $(2 \mathrm{H}, \mathrm{d}, J=8.8 \mathrm{~Hz}), 7.69(2 \mathrm{H}, \mathrm{d}, J=8.8 \mathrm{~Hz}), 7.90$ $(4 \mathrm{H}, \mathrm{dd}, J=5.4,8.4 \mathrm{~Hz}), 8.09(2 \mathrm{H}, \mathrm{d}, J=8.8 \mathrm{~Hz})$, $8.30\left(2 \mathrm{H}\right.$, s) $\mathrm{ppm} .{ }^{13} \mathrm{C}$ NMR $(75 \mathrm{MHz}) \delta\left(\mathrm{CDCl}_{3}\right)$ : 56.6, 115.4, 118.8, 125.4, 126.3, 127.7, 131.5, 132.5, 132.6, 134.3, 136.0, 157.1, 166.1, $195.0 \mathrm{ppm}$. Anal. Calcd. for $\mathrm{C}_{36} \mathrm{H}_{24} \mathrm{~F}_{2} \mathrm{O}_{4}$ : C, $77.41 \%$; H, 4.33\%. Found: $\mathrm{C}, 77.42 \%$; H, $4.23 \%$.

Polymerization of 6,6'-Bis(4-fluorobenzoyl)-2,2'-dimethoxy-1,1'-binaphthyl (3) with Arenediol (2) through Nucleophilic Aromatic Substitution Reaction

To a two-necked flask, 6,6'-bis(4-fluorobenzoyl)$2,2^{\prime}$-dimethoxy-1,1'-binaphthyl $(\mathbf{3}, 0.2 \mathrm{mmol})$, aromatic diol $(4,0.2 \mathrm{mmol})$, and potassium carbonate $(1.0$ mmol) were placed. Freshly distilled NMP $(0.5 \mathrm{~mL})$ was added to the flask. The mixture was stirred at $170^{\circ} \mathrm{C}$ for $6 \mathrm{~h}$. Reaction mixture was poured into $5 \mathrm{wt} \%$ sodium hydroxide solution and the mixture was extracted with $\mathrm{CHCl}_{3}$ three times. The combined extracts were washed with water and dried over anhydrous sodium sulfate. After filtration, the solvent was removed under reduced pressure. The precipitates were collected by suction filtration and dried in vacuo at $120^{\circ} \mathrm{C}$ to give a pale yellow solid of polymer $\mathbf{5}$.

Polyketone 5a: IR $v(\mathrm{KBr}): 1651,1595,1493,1226$ $\mathrm{cm}^{-1} .{ }^{1} \mathrm{H}$ NMR $(300 \mathrm{MHz}) \delta\left(\mathrm{CDCl}_{3}\right): 3.81(6 \mathrm{H}, \mathrm{s})$, $7.07(4 \mathrm{H}, \mathrm{d}, J=8.4 \mathrm{~Hz}), 7.14(4 \mathrm{H}, \mathrm{s}), 7.18(2 \mathrm{H}, \mathrm{d}$, $J=8.7 \mathrm{~Hz}), 7.52(2 \mathrm{H}, \mathrm{d}, J=8.7 \mathrm{~Hz}), 7.68(2 \mathrm{H}, \mathrm{d}$, $J=8.7 \mathrm{~Hz}), 7.88(4 \mathrm{H}, \mathrm{d}, J=8.4 \mathrm{~Hz}), 8.08(2 \mathrm{H}, \mathrm{d}$, $J=8.7 \mathrm{~Hz}), 8.31(2 \mathrm{H}, \mathrm{s}) \mathrm{ppm} .{ }^{13} \mathrm{C} \mathrm{NMR}(75 \mathrm{MHz})$ $\delta\left(\mathrm{CDCl}_{3}\right): 56.6,114.4,117.0,118.9,121.6,125.3$, $126.5,127.8,131.4,132.1,132.4,132.6,132.9$, 135.9, 152.1, 156.9, 161.4, 195.2 ppm. Anal. Calcd. for $\left(\mathrm{C}_{42} \mathrm{H}_{28} \mathrm{O}_{6}\right)_{n}: \mathrm{C}, 80.24 \%$; H, 4.49\%. Found: C, $79.69 \% ; \mathrm{H}, 4.43 \%$.

Polyketone 5b: IR v (KBr): 1651, 1487, $1217 \mathrm{~cm}^{-1}$. ${ }^{1} \mathrm{H}$ NMR $(300 \mathrm{MHz}) \delta\left(\mathrm{CDCl}_{3}\right): 3.81(6 \mathrm{H}, \mathrm{s}), 7.02-$ $7.11(12 \mathrm{H}, \mathrm{m}), 7.17(2 \mathrm{H}, \mathrm{d}, J=8.4 \mathrm{~Hz}), 7.51(2 \mathrm{H}$, d, $J=8.4 \mathrm{~Hz}), 7.67(2 \mathrm{H}, \mathrm{d}, J=8.4 \mathrm{~Hz}), 7.86(4 \mathrm{H}$, d, $J=8.1 \mathrm{~Hz}), 8.07(2 \mathrm{H}, \mathrm{d}, J=8.4 \mathrm{~Hz}), 8.30(2 \mathrm{H}, \mathrm{s})$ ppm. ${ }^{13} \mathrm{C}$ NMR $(75 \mathrm{MHz}) \delta\left(\mathrm{CDCl}_{3}\right): 56.6,114.4$, 116.8, 118.9, 120.1, 121.6, 125.3, 126.5, 127.8, 131.4, 132.0, 132.4, 132.9, 135.9, 151.0, 154.0, 156.9, 161.7, 195.2 ppm. Anal. Calcd. for $\left(\mathrm{C}_{48} \mathrm{H}_{32} \mathrm{O}_{7}\right)_{n}$ : C, $79.99 \%$; H, $4.47 \%$. Found: C, $79.23 \%$; H, $4.33 \%$.

Polyketone 5c: IR $v(\mathrm{KBr}): 1659,1589,1495,1240$ $\mathrm{cm}^{-1} .{ }^{1} \mathrm{H}$ NMR $(300 \mathrm{MHz}) \delta\left(\mathrm{CDCl}_{3}\right): 3.82(6 \mathrm{H}, \mathrm{s})$, 7.11-7.21 (10H, m), 7.51-7.56 (2H, m), 7.67-7.71 $(2 \mathrm{H}, \mathrm{m}), 7.84-7.93(8 \mathrm{H}, \mathrm{m}), 8.06-8.12(2 \mathrm{H}, \mathrm{m})$, $8.33(2 \mathrm{H}, \mathrm{s}) \mathrm{ppm} .{ }^{13} \mathrm{C} \mathrm{NMR}(75 \mathrm{MHz}) \delta\left(\mathrm{CDCl}_{3}\right)$ : 56.6, 114.5, 118.6, 118.7, 118.8, 125.4, 126.4, 127.8, $131.5,132.2,132.3,132.4,132.6,133.8,136.0$, 157.0, 159.6, 159.9, 194.1, 195.1 ppm. Anal. Calcd. for $\left(\mathrm{C}_{49} \mathrm{H}_{32} \mathrm{O}_{7}\right)_{n}$ : C, $80.31 \%$; H, 4.40\%. Found: C, $79.92 \% ; \mathrm{H}, 4.22 \%$.

\section{RESULTS AND DISCUSSION}

6,6'-Bis(4-fluorobenzoyl)-2,2'-dimethoxy-1,1'-binaphthyl $((S)-3)$ was prepared via electrophilic aromatic substitution reaction of optically pure $2,2^{\prime}$-dimethoxy-1,1'-binaphthyl $((S)-\mathbf{1})$ with 4-fluorobenzoic acid (2) in $\mathrm{P}_{2} \mathrm{O}_{5}-\mathrm{MsOH} .{ }^{25}$

Binaphthyl $(S)-\mathbf{3}$ was treated with hydroquinone (4a) in the presence of $\mathrm{K}_{2} \mathrm{CO}_{3}$ in DMAc, DMF, and NMP at $150-170^{\circ} \mathrm{C}$. Degree of polymerization was estimated by measurement of inherent viscosity in a concentrated $\mathrm{H}_{2} \mathrm{SO}_{4}$ solution and the ${ }^{1} \mathrm{H}$ NMR spectrum in $\mathrm{CDCl}_{3}$. The results are shown in Table I.

Among solvents screened, NMP was the most suitable to obtain high-molecular-weight poly(ether ketone)s. High basicity and high boiling point of the solvent are probably requisite for sustainable nucleophilic aromatic substitution polymerization. However, the slight residual signals of end groups were observed in the ${ }^{1} \mathrm{H}$ NMR spectrum, which indicates that the polymer is a tetramer and/or a pentamer on average.

Table II shows the results of polymerization of optically active binaphthyl $\mathbf{3}$ with several aromatic diols 4. When 4,4'-oxybisphenol (4b) was employed instead of hydroquinone (4a), the corresponding polyketone $(\mathbf{5 b})$ was obtained. The polyketone $(\mathbf{5 b})$ was a much

Table I. Nucleophilic aromatic substitution polymerization of hydroquinone (4a) with 6,6'-bis(4-fluorobenzoyl)-2,2'-dimethoxy-1,1'-binaphthyl ((S)-3)

\begin{tabular}{ccccccc}
\hline Run & Solvent $/ \mathrm{mL}$ & Temp. $/{ }^{\circ} \mathrm{C}$ & Time $/ \mathrm{h}$ & Yield $/ \%$ & $\eta_{\text {inh }} / \mathrm{dLg}^{-1}$ & Film $^{\mathrm{a}}$ \\
\hline 1 & DMAc $/ 0.5 \mathrm{~mL}$ & 150 & 48 & 72 & 0.15 & - \\
2 & $\mathrm{DMF} / 0.5 \mathrm{~mL}$ & 150 & 48 & 94 & 0.20 & + \\
3 & $\mathrm{NMP} / 0.5 \mathrm{~mL}$ & 170 & 6 & 92 & 0.29 & ++ \\
4 & $/ 1 \mathrm{~mL}$ & 170 & 6 & 69 & 0.21 & ++ \\
\hline
\end{tabular}

Reaction conditions: hydroquinone (4a), $0.2 \mathrm{mmol}$; $(S)-\mathbf{3}, 0.2 \mathrm{mmol} ; \mathrm{K}_{2} \mathrm{CO}_{3}, 1.0 \mathrm{mmol} ; \mathrm{N}_{2} .{ }^{\mathrm{a}}++$, flexible; + , brittle; - not obtained. 


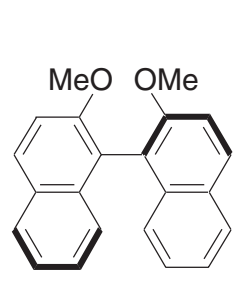

(S)-1
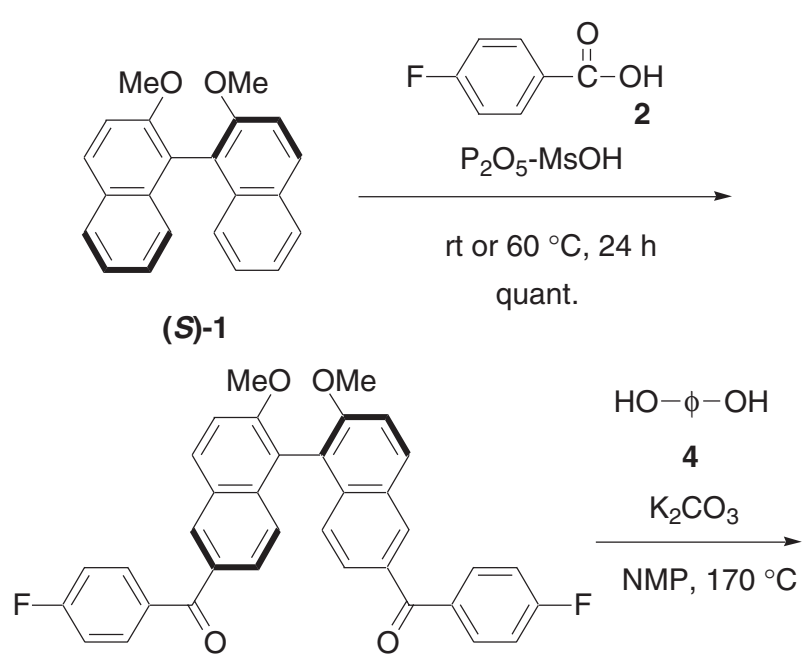

(S)-3

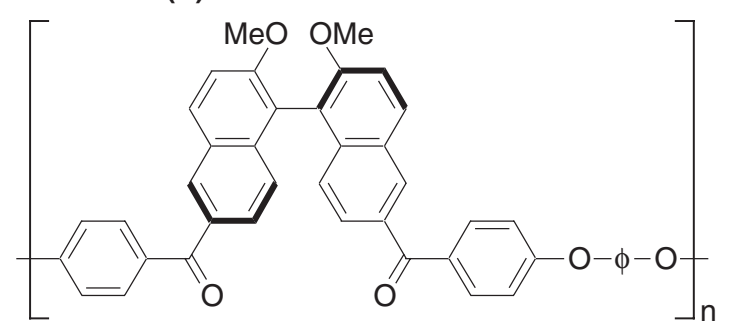

(S)-5

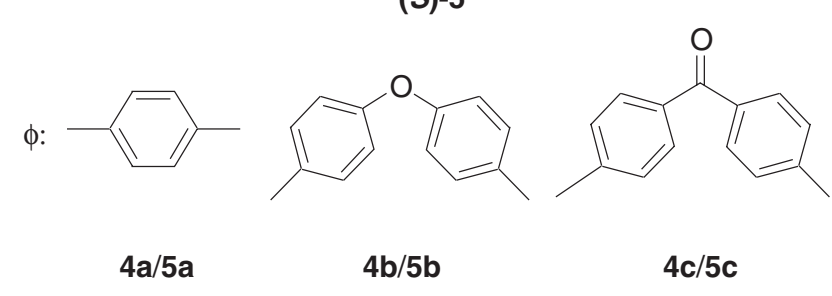

Scheme 1.

more flexible film than polyketone 5a. No residual signals assignable to end groups were observed in the ${ }^{1} \mathrm{H}$ NMR spectrum of polymer $\mathbf{5 b}$. In addition, the inherent viscosity of the polyketone $(\mathbf{5 b})$ was $0.80 \mathrm{dL} / \mathrm{g}$. These results indicate that sufficiently high-molecular-weight polyketone (5b) is obtained. On the other hand, polyketone $\mathbf{5 c}$ obtained in the reaction of 4,4'-hydroxybenzophenone (4c) has almost the same degree of polymerization as polyketone $\mathbf{5 a}$.

The specific rotation values of the resulting poly(ether ketone)s $((S)-\mathbf{5 a}-\mathbf{c})$ are shown in Table II. No drastic difference in specific rotation was observed between polymers $\mathbf{5 a}-\mathbf{c}$ and monomer $(S)-\mathbf{3 a}$, i.e., $76^{\circ}$. Though the polymerization at high temperature has the danger of racemization, the product after stirring a DMAc solution of monomer $(S)-3 \mathbf{a}$ and $\mathrm{K}_{2} \mathrm{CO}_{3}$ at $170{ }^{\circ} \mathrm{C}$ for $6 \mathrm{~h}$ had the same specific rotation value as the starting material, which indicates that no racemization occurs during polymerization.

CD spectra of polyketones $(S)-\mathbf{5 a}-\mathbf{c}$ and monomer $(S)-\mathbf{3}$ in $\mathrm{CHCl}_{3}$ are shown in Figure 1. Monomer (S)-3 exhibited bisignate Cotton effects at 283 and $328 \mathrm{~nm}$. However, the $\mathrm{CD}$ spectrum of polyketone 5a showed a drastic decrease in intensity and those of polyketones $\mathbf{5 b}$ and $\mathbf{5 c}$ showed no Cotton effects. These undesirable results indicate that polyketones have no specific secondary structures such as helix. More rigid backbones than polyketones $\mathbf{5}$ will be requisite for control of secondary structures.

The thermal characteristics of the poly(ether ketone)s (5) are also shown in Table II. Glass transition temperatures are $147-180^{\circ} \mathrm{C}$. Introduction of polar functional groups such as carbonyl and ether units raises glass transition temperatures of the polyketones. In TGA measurements, polyketones 5 were thermally stable to $\mathrm{ca} .400{ }^{\circ} \mathrm{C}$ and started to decompose gradually. The temperatures are almost the same as those where 2,2'-dimethoxy-5,5'-biphenylene-containing wholly aromatic polyketones start to decompose..$^{15}$ The similar thermal behavior suggests that the thermal decomposition in both polymers occur with cleavage of methoxy groups situated at $2,2^{\prime}$-positions as a start.

In conclusion, polymerization of 6,6'-bis(4-fluorobenzoyl)-2,2'-dimethoxybinaphthyl $\mathbf{3}$ with aromatic diol 4 in the presence of $\mathrm{K}_{2} \mathrm{CO}_{3}$ proceeds with sustainable reactivity and excellent regioselectivity, giving the corresponding aromatic polyketones (5) containing axial asymmetry. Among aromatic polyketones screened, the polyketone derived from 4,4'oxybiphenol was the highest-molecular-weight one.

Table II. Synthesis of optically active aromatic poly(ether ketone)s $(S)-\mathbf{5}$ via nucleophilic aromatic substitution polymerization of aromatic diols $\mathbf{4}$ with $(S)-\mathbf{3}$

\begin{tabular}{ccccccccc}
\hline Run & Diol $\mathbf{4}$ & Product $\mathbf{5}$ & Yield $/ \%$ & $\eta_{\text {inh }} / \mathrm{dLg}^{-1 \mathrm{a}}$ & Film $^{\mathrm{b}}$ & {$[\alpha]_{\mathrm{D}}{ }^{25} / \mathrm{deg}^{\mathrm{c}}$} & $T_{\mathrm{g}} /{ }^{\circ} \mathrm{C}^{\mathrm{d}}$ & $T_{\mathrm{d} 10} /{ }^{\circ} \mathrm{C}^{\mathrm{e}}$ \\
\hline 1 & $\mathbf{4 a}$ & $\mathbf{5 a}$ & 92 & 0.29 & ++ & +34 & 147 & 403 \\
2 & $\mathbf{4 b}$ & $\mathbf{5 b}$ & 97 & 0.80 & ++ & +31 & 170 & 404 \\
3 & $\mathbf{4 c}$ & $\mathbf{5 c}$ & 88 & 0.35 & ++ & +29 & 180 & 403 \\
\hline
\end{tabular}

Reaction conditions: aromatic diol 4, $0.2 \mathrm{mmol}$; $(S)$-6,6'-bis(4-fluorobenzoyl)-2,2'-dimethoxy-1,1'-binaphthyl (3), $0.2 \mathrm{mmol} ; \mathrm{K}_{2} \mathrm{CO}_{3}, 1.0 \mathrm{mmol}$; NMP, $0.5 \mathrm{~mL} ; 170{ }^{\circ} \mathrm{C}$; under $\mathrm{N}_{2}$. ${ }^{a}$ Determined in a concentrated $\mathrm{H}_{2} \mathrm{SO}_{4}$ solution $(0.3 \mathrm{~g} / \mathrm{dL})$ at $30^{\circ} \mathrm{C} .{ }^{\text {b }}++$, obtained as a flexible film. ${ }^{\mathrm{c}}[\alpha]_{\mathrm{D}}{ }^{25}$ was measured in a $\mathrm{CHCl}_{3}$ solution $(0.3 \mathrm{~g} / \mathrm{dL})$. ${ }^{\mathrm{d}}$ Determined on the basis of DSC curves. Heating rate: $10 \mathrm{~K} / \mathrm{min}$. ${ }^{\mathrm{e}}$ Temperature where a $10 \mathrm{wt} \%$ loss was recorded by TG. ${ }^{\mathrm{f}} M_{\mathrm{n}}: 20400 . M_{\mathrm{w}}: 118000 . M_{\mathrm{w}} / M_{\mathrm{n}}: 5.80$. Determined by GPC using narrow molecular weight PS as standards (column: Shodex KD-806M. eluent: $\mathrm{CHCl}_{3}$. UV detector: $300 \mathrm{~nm}$ ). 


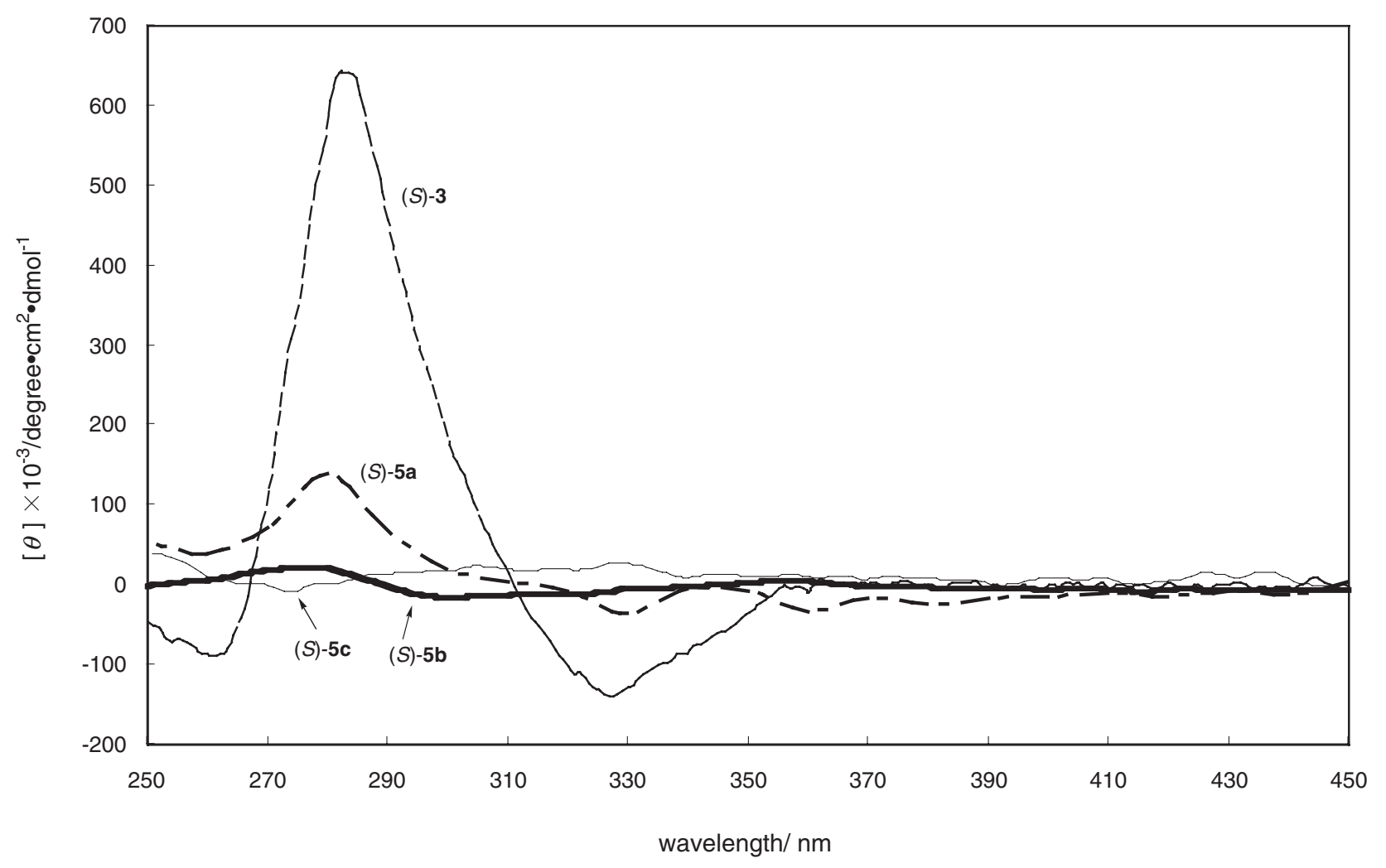

Figure 1. $\mathrm{CD}$ spectra of polyketones $\mathbf{5 a}-\mathbf{c}$ and monomer 3 in $\mathrm{CHCl}_{3}$ (c: $c a \cdot 10^{-5} \mathrm{~mol} / \mathrm{L}$ ).

The exclusion of flexible ether bonds from the main chains, i.e., wholly aromatic polyketones, will lead to the control of secondary structures of polymers.

\section{REFERENCES}

1. R. Noyori, Chem. Soc. Rev., 18, 187 (1989).

2. Q.-S. Hu, X.-F. Zheng, and L. Pu, J. Org. Chem., 61, 5200 (1996).

3. S. Habaue, T. Seko, and Y. Okamoto, Macromolecules, 35, 2437 (2002).

4. G. Koeckelberghs, S. Sioncke, T. Verbiest, I. V. Severen, I. Picard, A. Persoons, and C. Samyn, Macromolecules, 36, 9736 (2003).

5. F. Kondo, D. Takahashi, H. Kimura, and M. Takeishi, Polym. J., 30, 161 (1998).

6. H. Kimura, D. Takahashi, T. Yamaguchi, and M. Takeishi, Sen-i Gakkaishi, 56, 169 (2000).

7. T. Takata, Y. Furusho, K. Murakawa, T. Endo, H. Matsuoka, T. Hirasa, J. Matsuo, and M. Sisido, J. Am. Chem. Soc., 120, 4530 (1998).

8. M. Teraguchi, Y. Horikawa, M. Kumata, T. Kaneko, and T. Aoki, Polym. Prepr., Jpn., 53, 2928 (2004).

9. P. A. Staniland, "Comprehensive Polymer Science," Vol. 5, G. C. Eastmond, A. Ledwith, S. Russo, and P. Sigwalt, Ed., Pergamon Press, Oxford, U.K., 1989, p 483.

10. N. Yonezawa, J. Synth. Org. Chem. Jpn., 53, 172 (1995).

11. N. Yonezawa, S. Mori, S. Miyata, Y. Ueha-Anyashiki, and K. Maeyama, React. Funct. Polym., 53, 11 (2002).

12. M. G. Zolotukhin, H. M. Colquhoun, L. G. Sestiaa, D. R.
Rueda, and D. Flot, Macromolecules, 36, 4766 (2003).

13. N. Yonezawa, S. Miyata, T. Nakamura, S. Mori, Y. Ueha, and R. Katakai, Macromolecules, 26, 5262 (1993).

14. N. Yonezawa, T. Namie, T. Ikezaki, T. Hino, H. Nakamura, Y. Tokita, and R. Katakai, React. Funct. Polym., 20, 261 (1996).

15. N. Yonezawa, S. Mori, S. Miyata, Y. Ueha-Anyashiki, S. M. Wu, and K. Maeyama, Polym. J., 35, 998 (2003).

16. N. Yonezawa, A. Kameda, T. Jobashi, S. Maruyama, and K. Maeyama, Polym. J., 36, 345 (2004).

17. K. Maeyama Y. Tagata, and N. Yonezawa, Polym. J., 36, 145 (2004).

18. K. Maeyama, Y. Tagata, H. Nishimori, M. Yamazaki, S. Maruyama, and N. Yonezawa, React. Funct. Polym., 61, 71 (2004).

19. N. Yonezawa, T. Ikezaki, H. Nakamura, and K. Maeyama, Macromolecules, 33, 8125 (2000).

20. K. Maeyama, S. Sekimura, M. Takano, and N. Yonezawa, React. Funct. Polym., 58, 111 (2004).

21. K. Maeyama, T. Kinuno, T. Jobashi, and N. Yonezawa, React. Funct. Polym., 59, 155 (2004).

22. K. Maeyama, T. Ohe, H. Nakamura, and N. Yonezawa, Polym. J., 35, 290 (2003).

23. K. Maeyama, T. Ohe, H. Nakamura, and N. Yonezawa, Polym. J., 35, 1005 (2003).

24. P. E. Eaton and G. R. Carlson, J. Org. Chem., 38, 4071 (1973).

25. K. Maeyama, K. Ogura, A. Okamoto, K. Sakurai, Y. Yoshida, K. Ogino, and N. Yonezawa, Synth. Commun., 34, 3243 (2004). 